\title{
VARIABILITY BETWEEN Helianthus tuberosus ACCESSIONS COLLECTED IN THE USA AND MONTENEGRO
}

\author{
D, Vasić, J. Miladinović, A. Marjanović-Jeromela, D. Škorić
}

Institute of Field and Vegetable Crops, M. Gorkog 30, 21000 Novi Sad, Yugoslavia

Received: February 08, 2002

Accepted: October 25, 2002

\section{SUMMARY}

Morphological variability between accessions of $H$. tuberosus collected in Montenegro and the USA was investigated as well as possible effect of longterm cultivation or its absence and growing in different environmental conditions on morphological traits of this species. Results obtained showed that there is a large similarity between some populations collected in Montenegro and those collected in the USA. This, along with the presence of a great cluster formed exclusively from Montenegrin populations, supports the hypothesis that there were two ways of introduction of $H$. tuberosus to Montenegro. In a group of populations, the changes in morphology were found, probably due to absence of cultivation.

Key words: Helianthus tuberosus, morphological traits, variability, cluster analysis

\section{INTRODUCTION}

Helianthus tuberosus L. belongs to the section Divarcati, series Divarcati of the genus Helianthus (Rogers et al., 1982). This species is one of the most widespread sunflower species and it can be found in almost all parts of the USA and also in other parts of the world. $H$. tuberosus is very interesting from the agronomic aspect, because it has genes of resistance to many dominant sunflower diseases and pests (Pustavoit and Krasnokutskaya, 1976; Škorić and Vanozzi, 1984).

$H$. tuberosus is an extremely variable species. One unifying feature is the possession of tubers, although they vary greatly in size, color and shape. It was found that some of the important diagnostic characters of the leaves, especially leaf arrangement, can be strongly influenced by environmental conditions and absence or presence of cultivation, although there are hypotheses that some variation of these characters is genetic (Heiser et al., 1969).

* corresponding author: e-mail: vasicd@ifvcns.ns.ac.yu 
H. tuberosus was mostly introduced in Montenegro during and after World War II. First it was cultivated and then it spread as a weed.

The objective of our work was to determine morphological variability between accessions of $H$. tuberosus collected in Montenegro and the USA and to detect possible effect of long-term cultivation or its absence and growing in different environmental conditions on morphological traits of this species.

\section{MATERIAL AND METHODS}

Morphological traits of 79 accessions of $H$. tuberosus were investigated; 13 accessions were collected in the USA (TUB) and 66 in Montenegro, Yugoslavia (CG). All accessions were grown in the wild species nursery of the Institute of Field and Vegetable Crops, Novi Sad, Yugoslavia.

Thirty-one traits were evaluated according to IBPGR Descriptor (IBPGR, 1985). These were: flowering uniformity, plant height, leaf size, shape, color, anthocyanin coloration, glossiness, margin, base, shape of cross section and angle of lateral veins, height of the tip of the leaf blade compared to insertion of petiole, petiole length, hairiness at the top of stem, length of internodes, bud opening before flowering, bract pubescence, shape, size, peak and length, number, shape and color of ray flower, color of disk flower, anthocyanin coloration of stigma, head angle, size and shape and presence and type of branching.

The obtained data were used for grouping the accessions. As the method for grouping we used group analysis, and for estimating the differences between the groups, euclidian units were used, where distance $\mathrm{x}, \mathrm{y}=\left(\Sigma_{\mathrm{i}}\left(\mathrm{x}_{\mathrm{i}}-\mathrm{y}_{\mathrm{i}}\right)^{2}\right)^{1 / 2}$. Groups of accessions were separated using single linkage method.

\section{RESULTS AND DISCUSSION}

The united dendrogram for all collected accessions could be divided into three groups. The first group consisted of ten USA and Montenegrin populations that differed significantly both among themselves and from all others (Figure 1). Similar morphological divergence within this species with certain populations forming separate groups was also observed by Dozet et al. (1993, 1994). These accessions generally differed from all others in plant height, being shorter than the rest of the collection. This could be due to absence of cultivation, as it was actually the case with Montenegrin accessions, since certain varieties of $H$. tuberosus tend to produce shorter plants when grown without cultivation for several years (Heiser, 1969). Great morphological similarity of populations CG56 and TUB2017 could point out to recent introduction of the population CG56.

As in work of Dozet et al. (1993), 51 populations collected in Montenegro formed a separate cluster (Figure 1). These populations, collected over a small geo- 


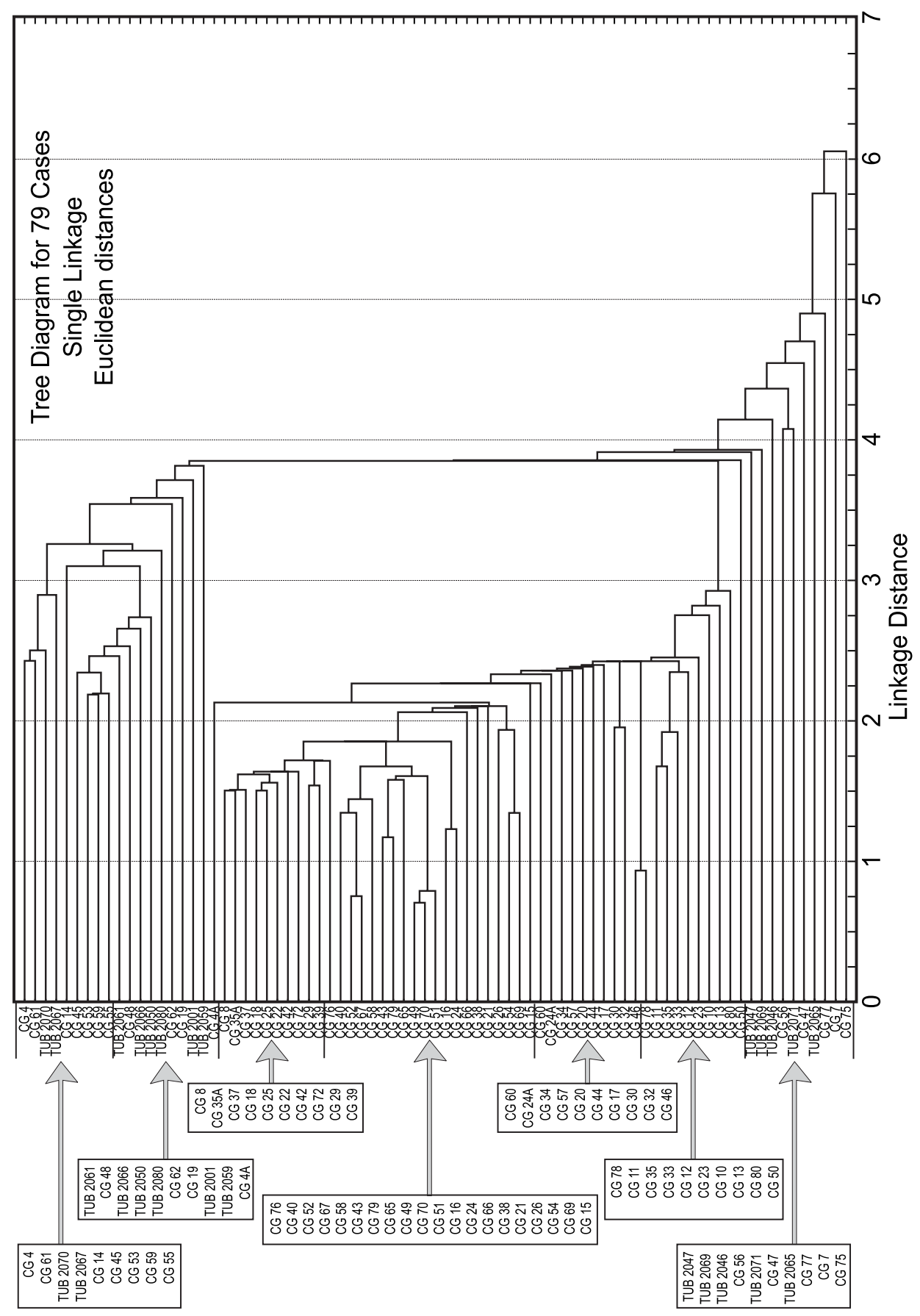

Figure 1: Tree diagram of the H. tuberosus accessions 
graphic distance, were similar to each other, though some variability could be seen, as in accession CG50 that was in a separate subgroup.

The third group consisted of Montenegrin and USA populations that were generally similar to each other. A great similarity of some Montenegrin populations with the populations from the USA as well as a clear separation of a large group of Montenegrin populations from the rest of the accessions, supports the hypothesis that there were two major parts of $H$. tuberosus introduction to Montenegro (Dozet et al., 1993). One path leads from north and continental Europe and the other from marine ports, populations being introduced mostly from the USA.

\title{
CONCLUSIONS
}

The results obtained showed that there is a great similarity between some populations collected in Montenegro and those collected in the USA. This, along with the presence of a great cluster formed exclusively from Montenegrin populations, supports the hypothesis that there were two ways of introduction of $H$. tuberosus to Montenegro. In a group of populations, changes in morphology were found, probably due to absence of cultivation.

\section{REFERENCES}

Dozet, B., Marinković, R., Vasić, D. and Marjanović, A., 1993. Genetic similarity of the Jerusalem artichoke populations (Helianthus tuberosus L.) collected in Montenegro. Helia 16(18): 41-48.

Dozet, B., Marinković, R., Atlagić, J. and Vasić, D., 1994. Genetic divergence in Jerusalem artichoke (Helianthus tuberosus L.). In: Proc. Genet. Resour. Sect. Meeting EUCARPIA, Clermont-Ferrand, France, pp. 47-48.

Heiser, C.B., Smith, D. and Martin, W., 1969. The North American sunflower (Helianthus). Mem. Torrey Bot. Club 22(3): 1-218.

IBPGR, 1985. Descriptors for cultivated and wild sunflower. IBPGRI Secretariat, Rome.

Pustavoit, G.V., Krasnokurtskaya, O.N., 1976. Wild species of Helianthus as initial forms for breeding for sunflower immunity. In: Proc. VII Sunflow. Conf. pp. 64-67.

Rogers, C.E., Thompson, T.E. and Seiler, G.J., 1982. Sunflower species of the United States. National Sunflower Association, Fargo, ND, USA, pp. 75.

Škorić, D., Vanozzi, G.P., 1984. Genetic resources in Helianthus genus. Internat Sympos. Sci. Biotechnol, Bari, Italy, pp. 37-73.

\section{VARIABILIDAD DE MUESTRAS DE LA ESPECIE Helianthus tuberosis RECOLECTADAS EN LOS EEUU Y EN MONTENEGRO}

\author{
RESUMEN
}

Se ha investigado la variabilidad morfológica de las muestras de la especie $H$. tuberosus recolectadas en Montenegro y en los EEUU, y los posibles efectos de cultivo de varios años o la ausencia de cultivo, tanto como la branza en las diferentes condiciones del medio exterior, en las características morfológicas de esta especie. Los resultados obtenidos han mostrado que existe 
una gran similitud entre ciertas poblaciones recolectadas en Montenegro, y poblaciones recolectadas en los EEUU. Este hecho, tanto como la presencia de gran cluster formado exclusivamente de las poblaciones montenegrinas, viene en beneficio de la suposición que esta especie ha llegado a Montenegro de dos maneras diferentes. Se ha determinado que en un grupo de poblaciones se han generado los cambios morfológicos, probablemente como resultado de la ausencia de cultivo.

\section{VARIABILITÉ DES ÉCHANTILLONS DE Helianthus tuberosus RECUEILLIS AUX ÉTATS-UNIS ET AU MONTÉNÉGRO}

\section{RÉSUMÉ}

La recherche portait sur la variabilité morphologique entre les échantillons de $H$. tuberosus recueillis au Monténégro et aux États-Unis ainsi que sur l'effet possible de la culture à long terme ou de l'absence de culture ainsi que la culture dans différentes conditions environnementales sur les caractéristiques morphologiques de cette espèce. Les résultats obtenus montrent qu'il y a une grande similarité entre certaines populations recueillies au Monténégro et d'autres recueillies aux États-Unis. Ceci ainsi que la présence d'un grand cluster formé exclusivement de la population monténégrine appuie l'hypothèse que l'espèce a été introduite au Monténégro de deux manières. Dans un groupe de populations, des changements dans la morphologie ont été constatés et ils sont probablement dûs à l'absence de culture. 
